\title{
Heterogeneity of Opioid Receptor Binding in Brain Slices
}

\author{
C.C. Barchfeld-Rothschild and F. Medzihradsky \\ Departments of Biological Chemistry and Pharmacology, The University of Michigan Medical School, \\ Ann Arbor
}

A methodological approach was established for the study of ligand binding to multiple opioid receptors in slices from rat brain striatum. Specific binding of radiolabeled opiates was resolved from total binding with enantiomers or excess unlabeled ligand. Equilibrium binding of triated etorphine, dihydromorphine, and ethylketocyclazocine, and competitive displacement of $\left[{ }^{3} \mathrm{H}\right]$ etorphine and $\left[{ }^{3} \mathrm{H}\right]$ dihydromorphine by the unlabeled opiates were used to assess both high and low affinity receptor sites. The high-affinity binding components of the radiolabeled opiates were characterized by linear Scatchard plots, $K_{d}$ values of 2.8$3.7 \mathrm{nM}$, and binding site densities of $180-297 \mathrm{fmol} / \mathrm{mg}$ protein. The displacement of $\left[{ }^{3} \mathrm{H}\right]$ etorphine by morphine and ethylketocyclazocine displayed Hill coefficients of 0.62 and 0.47 , respectively, and revealed receptor sites with much lower affinities than those described by the direct binding of these opiates. On the other hand, both morphine and ethylketocyclazocine displaced $\left[{ }^{3} \mathrm{H}\right]$ dihydromorphine with similar high potencies (apparent $K_{d}$ 's, 3-4 nM). The results support the feasibility of using brain slices as a cellular preparation to study opioid receptor mechanisms.

Key words: multiple opioid receptors, rat brain, $\left[{ }^{3} \mathrm{H}\right]$ dihydromorphine, $\left[{ }^{3} \mathrm{H}\right]$ ethylketocyclazocine, $\left[{ }^{3} \mathrm{H}\right]-$ etorphine

\section{INTRODUCTION}

During recent years, marked advances have been made in describing the binding of opiates to multiple opioid receptors in isolated brain membranes [e.g., Gillan and Kosterlitz, 1982; James and Goldstein, 1984]. Since various tissue constituents such as ions and nucleotides markedly influence the interaction of opiates with their receptor [Blume, 1978; Blume et al, 1979; Chang et al, 1983], in numerous studies these components were included in the medium of the binding assay with isolated membranes. As an alternative, a procedure for the assessment of opioid receptor binding in vivo was developed based on an assay in tissue homogenates isolated from rats injected with radiolabeled opiates. Using this approach, binding profiles and potencies different than those obtained in isolated membranes were described [Rosenbaum et al, 1984]. In addition, autoradiographic studies with selective radiolabeled opiates have described the distinctive, differential localization of the opioid receptor types in brain [Herkenham and Pert, 1981; Goodman and Snyder, 1982].

The study of ligand interaction with opioid receptor in isolated intact cells imposes considerable methodological difficulties, particularly the involvement of free ligand in processes other than receptor binding. Therefore, in studies with the NG108-15 neuroblastoma-glioma hybrids, containing only the delta receptor, the cells were homogenized prior to the binding assay [e.g., Simantov et al, 1982]. The assay of opioid receptor binding was also described in brain slices [Davis et al, 1977; Jacobson and Wilkinson, 1984] and, recently, the binding of $\left[{ }^{3} \mathrm{H}\right]$ naloxone to opioid receptor in freshly isolated brain cells was reported [Rogers and El-Fakahany, 1985]. However, in these studies multiple opioid receptors were not considered, and only a narrow range of low concentrations of the radiolabeled ligands was used. In brain membranes, we have investigated both the equilibrium binding and kinetics of ligand association and dissociation as approaches to characterize the interaction of opiates with multiple receptor binding sites [Fischel and Medzihradsky, 1981, 1986]. In that tissue, we have also described the resolution of multiple opioid receptors on the basis of (a) their differential sensitivity towards sodium [Medzihradsky et al, 1984], (b) receptor alkylation [Clark and Medzihradsky, 1986], and (c) receptor coupling to brain GTPase [Clark et al, 1986; Clark and Medzihradsky, 1987].

Dr. C. Barchfeld-Rothschild's present address is Department of Biochemistry, Wake Forest University, Bowman Gray School of Medicine, Winston-Salem, NC 27103.

Received January 23, 1987; revised April 7, 1987; accepted April 8, 1987.

Address reprint requests to Dr. Medzihradsky, Department of Biological Chemistry, The University of Michigan Medical School, Ann Arbor, MI 48109. 
Considering the information obtained with isolated membranes, the known regulatory roles of tissue constituents, and the different characteristics of opiate binding in vivo, it was of interest to investigate the heterogeneity of ligand interaction with opioid receptor in an intact cellular system from brain. The information obtained from such studies is essential for the characterization of these receptors in vivo, e.g., by the use of positron emission tomography [Frost et al, 1984]. Brain slices represent a conveniently available cellular preparation in which cell-cell interaction, e.g., between neurons and glia, is preserved. Thus, they complement the use of primary cultures of neural cells from brain [Fischel and Medzihradsky, 1985]. We have previously described the receptor-mediated inhibition of prostaglandin $\mathrm{E}$ (PGE)- induced adenylate cyclase by opiates in brain slices [Barchfeld et al, 1982], a coupling process abolished in isolated membranes [Katz and Catravas, 1977]. In the present study we have now investigated ligand binding to opioid receptor in slices from rat brain striatum, using kinetic approaches suitable to assess multiple binding sites with diverging affinities for different types of opiates.

\section{MATERIALS AND METHODS}

\section{Materials}

$\left[{ }^{3} \mathrm{H}\right]$ Dihydromorphine $\left(\left[{ }^{3} \mathrm{H}\right] \mathrm{DHM}\right), 71 \mathrm{Ci} / \mathrm{mmol}$; $\left[{ }^{3} \mathrm{H}\right]$ ethylketocyclazocine $\left(\left[{ }^{3} \mathrm{H}\right] \mathrm{EKC}\right), 20 \mathrm{Ci} / \mathrm{mmol}$; and $\left[{ }^{14} \mathrm{C}\right]$ inulin, $1.7 \mathrm{mCi} / \mathrm{g}$, were obtained from New England Nuclear Corporation (Boston, MA). [ $\left.{ }^{3} \mathrm{H}\right]$ etorphine

\section{A. RESOLUTION OF BINDING}
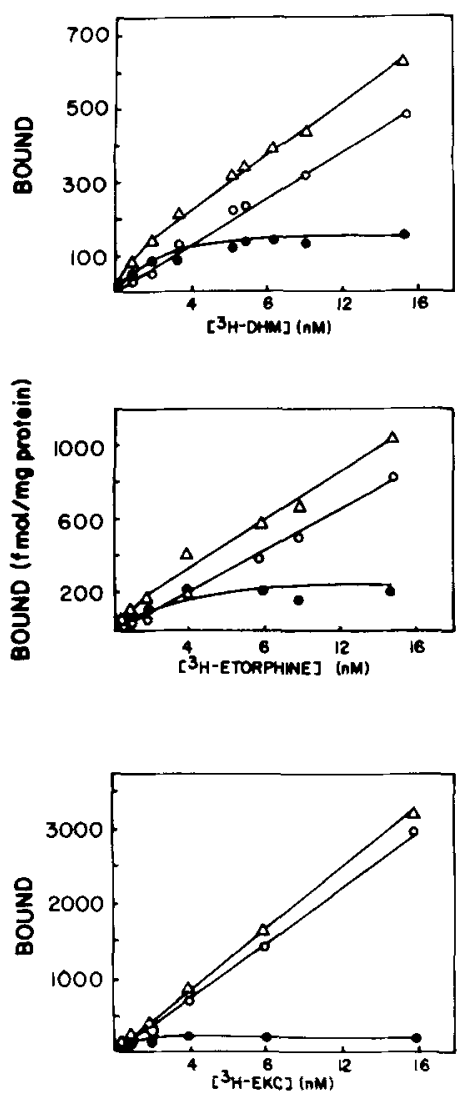

Fig. 1. A: Concentration-dependent binding of $\left[{ }^{3} \mathrm{H}\right]$ opiates in striatal slices. Slices, suspended in oxygenated artificial cerebrospinal fluid medium, were incubated for $15 \mathrm{~min}$ at $25^{\circ} \mathrm{C}$ in the absence or presence of $10 \mu \mathrm{M}$ unlabeled morphine, etorphine, or ethylketocyclazocine. Subsequently, $\left[{ }^{3} \mathrm{H}\right] \mathrm{DHM},\left[{ }^{3} \mathrm{H}\right] \mathrm{ET}$, or $\left[{ }^{3} \mathrm{H}\right]$ EKC were added at the concentrations indicated. After incubation for $20 \mathrm{~min}$ (ET) or $40 \mathrm{~min}$ (DHM and EKC) at $25^{\circ} \mathrm{C}$ to attain binding equilibrium, the assay was terminated by rapid filtration. Specific binding $(\bullet)$ was defined as the difference between total binding $(\triangle)$ and nonsaturable binding $(O)$, and was determined as described in
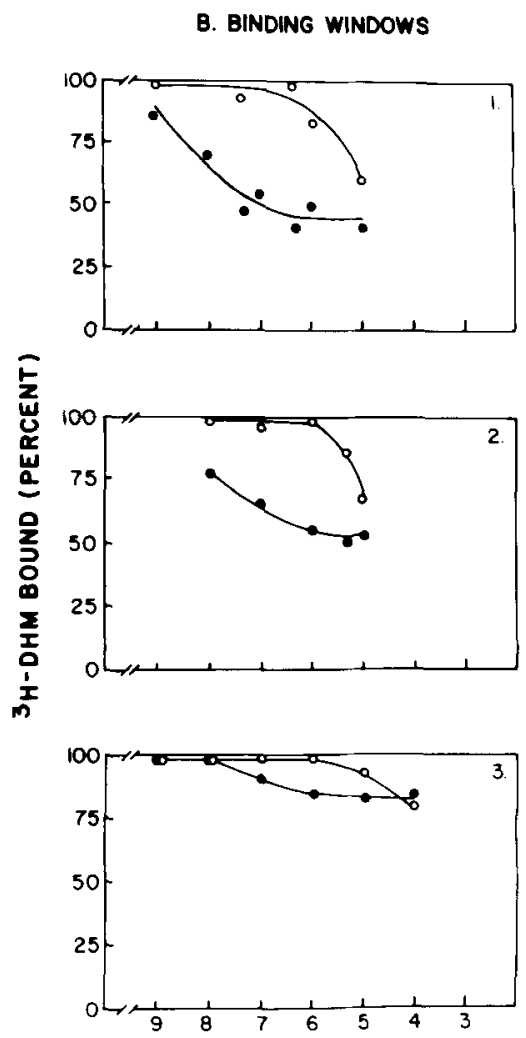

Materials and Methods. Presented are the mean values of results obtained in three experiments each carried out in duplicate. B: Displacement of bound $\left[{ }^{3} \mathrm{H}\right] \mathrm{DHM}$ by levorphanol and dextrorphan. Slices were incubated for $15 \mathrm{~min}$ as described above in the presence of either levorphanol (O) or dextrorphan $(O)$ at the concentrations indicated. Subsequently, $\left[{ }^{3} \mathrm{H}\right] \mathrm{DHM}$ was added to give a final concentration of $0.25 \mathrm{nM}$ (top panel), $2 \mathrm{nM}$ (middle panel), or $20 \mathrm{nM}$ (lower panel). After additional incubation for $40 \mathrm{~min}$, the assay was terminated by rapid filtration. Shown are the results of a representative experiment carried out in duplicate. 
$\left(\left[{ }^{3} \mathrm{H}\right] \mathrm{ET}\right), 37 \mathrm{Ci} / \mathrm{mmol}$, was purchased from Amersham Corporation (Arlington Heights, IL). The radiochemical purity of these compounds was listed as greater than $98 \%$. This information from the supplier was verified by thin-layer chromatography in solvent systems recommended by the manufacturers. The unlabeled opiates were obtained through the Drug Abuse Basic Research Center at the University of Michigan. Biochemicals were obtained from Sigma Chemical Company (St. Louis, MO). Other chemicals were of the reagent grade. The nylon cloth of specific mesh sizes (Nitex) was purchased from Tetco, Inc. (Elmsford, NY).

\section{Opioid Receptor Binding in Brain Slices}

Male Sprague-Dawley rats weighing $180 \mathrm{~g}$ were decapitated; the brains were quickly excised and transferred to $2-4^{\circ} \mathrm{C}$. The striata were dissected and cut into $400-\mu$ m-thick slices using a Brinkmann-Mcllwain tissue slicer. By means of fire-polished Pasteur pipettes, the slices were dispersed (one-half striata per sample) in 1.9 $\mathrm{ml}$ of oxygenated artificial cerebrospinal fluid medium, pH 7.4 and 333 mOsmol of the following composition (mM): $\mathrm{NaCl}, 125.0 ; \mathrm{KCl}, 1.8 ; \mathrm{CaCl}_{2}, 1.3 ; \mathrm{MgSO}_{4}, 1.2$; $\mathrm{K}_{2} \mathrm{PO}_{4}, 1.2 ; \mathrm{NaHCO}_{3}, 25.0$; glucose, 10.0. Deionized water or an excess of unlabeled opiate (to determine specific binding) was added in a volume of $50 \mu \mathrm{l}$, and the slices were allowed to incubate for $15 \mathrm{~min}$ at $25^{\circ} \mathrm{C}$ with constant bubbling of $95 \% \mathrm{CO}_{2}-5 \% \mathrm{O}_{2}$ through the medium. The rate of gassing was adjusted to maintain the $\mathrm{pH}$ at 7.4 throughout the experiment. Subsequently, the radiolabeled opiate was added and the suspension of slices were incubated at $25^{\circ} \mathrm{C}$ for varying lengths of time as indicated in the respective figure legends. The incubation was terminated by quickly filtering the sample through glass-fiber filters (Reeve-Angel 934AH) which had been soaked with water and rinsed with $0.9 \%$ icecold $\mathrm{NaCl}$ saturated with n-amyl alcohol [Medzihradsky, 1976]. Following washing with $3 \times 4 \mathrm{ml}$ of cold $0.9 \%$ $\mathrm{NaCl}$, the filters were placed in a plastic scintillation vial and the tissue digested with $2 \mathrm{ml}$ of $\mathrm{NaOH}$ for $1 \mathrm{hr}$ at $60^{\circ} \mathrm{C}$. After cooling to room temperature, $2 \mathrm{ml}$ of $1 \%$ deoxycholate were added, and the samples were placed in a shaking water bath for $30 \mathrm{~min}$. Subsequently, aliquots were removed for scintillation counting and protein determination.

Specific $\left[{ }^{3} \mathrm{H}\right.$ lligand binding was defined either as the difference between binding in the presence of $D$ - and L-opiate (e.g., dextrorphan and levorphanol), or the difference between binding in the absence and presence of $10 \mu \mathrm{M}$ of the corresponding unlabeled opiate. That concentration was obtained from displacement curves established for all concentrations of the radiolabeled ligands used in this study (Fig. 1). The evaluation of these approaches is described under Results.

\section{Determination of Protein}

The method of Lowry et al [1951] was applied. In order to compensate for potential interference by components of the assay systems [Peterson, 1979], the standards of crystallized, liophylized bovine serum albumin were prepared with the same constituents present in the samples being assayed.

\section{Determination of Cellular Potassium and Sodium}

After incubation under the conditions described for opioid receptor binding, the suspension of slices was filtered on $110-\mu \mathrm{m}$ mesh Nitex disks (cut out from corresponding sheets with a cork borer of appropriate diameter) supported by underlying Whatman $934 \mathrm{AH}$ glassfiber filters. Following washing on the filter with $4 \times 5$ $\mathrm{ml}$ of ice-cold $0.3 \mathrm{M}$ sucrose, $\mathrm{pH} 7.4$., the Nitex disks were transferred to $1.5-\mathrm{ml}$ polypropylene microcentrifuge tubes. After the addition of $400 \mu \mathrm{l}$ deionized water, the tissue was disrupted by sonication, using a Bronson sonifier with a microtip at power output 6 for $45 \mathrm{sec}$. The Nitex disks remained intact and were removed at this point. After aliquots were removed for the determination of protein, the sonicated tissue was digested with $50 \mu \mathrm{l} 70 \% \mathrm{HNO}_{3}$ for $2 \mathrm{hr}$ at $60^{\circ} \mathrm{C}$. Upon cooling to room temperature, $5 \mathrm{ml}$ of $15 \mathrm{mEq} / \mathrm{liter}$ of $\mathrm{LiCl}$ were added as internal standard, and the concentrations of $\mathrm{K}^{+}$and $\mathrm{Na}^{+}$were determined by flame photometry. To satisfy the requirement of sensitivity, approximately $2 \mathrm{mg}$ of protein per sample were required. The results are expressed as $\mu \mathrm{Eq}$ of cellular $\mathrm{K}^{+}$or $\mathrm{Na}^{+}$per mg protein, and were obtained by subtracting the corresponding extracellular concentration, represented by the extracellular space and ion concentration in the incubation medium, from the total ion content of the slices.

\section{Determination of Extracellular Space}

Slices were incubated in the presence of $0.5 \mu \mathrm{Ci}$ of $\left[{ }^{14} \mathrm{C}\right]$ inulin under the experimental condition of the binding assay. The incubation was terminated by filtering the slices on Whatman 934AH glass fiber filters, previously washed with deionized water and $0.9 \% \mathrm{NaCl}$. Following washing with $4 \times 4 \mathrm{ml}$ of ice-cold $0.9 \% \mathrm{NaCl}$, the filters were transferred to polypropylene counting vials, and digested for $60 \mathrm{~min}$ at $60^{\circ} \mathrm{C}$ with $1 \mathrm{ml}$ of $0.25 \mathrm{~N} \mathrm{NaOH}$. Aliquots of the digests were taken for the determination of protein and radioactivity. Inulin space was expressed as microliters per mg protein.

\section{RESULTS}

\section{Characteristics of the Binding Assay}

The viability of brain slices was ascertained by their ability to accumulate $\mathrm{K}^{+}$and maintain a positive gradient relative to the incubation medium throughout the incu- 
bations [Fischel and Medzihradsky, 1985]. The slices suspended in a medium with the composition of cerebrospinal fluid accumulated potassium to a concentration of $0.50 \mu \mathrm{Eq} / \mathrm{mg}$ protein. During incubations at $25^{\circ} \mathrm{C}$ of up to $120 \mathrm{~min}$, the ratio between the mean intracellular and extracellular concentrations of potassium was 46 , and the mean extracellular space was $2.73 \pm 0.86 \mu \mathrm{l} / \mathrm{mg}$ protein (corresponding to approximately $273 \mu \mathrm{l} / \mathrm{g}$ tissue wet weight). These characteristics compare favorably with such data reported for freshly isolated brain tissue [McIlwain and Rodnight, 1962] and slices [Pappius et al, 1962; Goodman et al, 1973].

Opioid receptor binding was defined as the difference between $\left[{ }^{3} \mathrm{H}\right]$ opiate bound in the absence and presence of an appropriate excess [Fischel and Medzihradsky, 1981] of the corresponding unlabeled opiate. Thus, for each of the three ligands used, $\left[{ }^{3} \mathrm{H}\right] \mathrm{DHM},\left[{ }^{3} \mathrm{H}\right] \mathrm{ET}$, and $\left[{ }^{3} \mathrm{H}\right] \mathrm{EKC}$, total ligand binding was resolved into saturable, receptor-related, and nonspecific, linear binding components (Fig. 1A). The specificity of saturable binding was ascertained by the use of enantiomers [Fischel and Medzihradsky, 1981]. As shown for $\left[{ }^{3} \mathrm{H}\right] \mathrm{DHM}$ (muselective), profiles of radiolabeled ligand displacement ("binding windows") were established using the muselective stereoisomer levorphanol (active) and its inactive counterpart dextrorphan (Fig. 1B). With increasing concentrations of the radiolabeled ligand, reflecting the range within which Scatchard analysis was carried out, the area of the window representing stereospecific binding decreased owing to the increased proportion of nonspecific binding. At appropriate concentrations of levorphanol and dextrorphan, the binding window was open to its widest extent because of the minimal and maximal displacement of $\left[{ }^{3} \mathrm{H}\right] \mathrm{DHM}$ by dextrorphan and levorphanol, respectively. Throughout the concentration range of $\left[{ }^{3} \mathrm{H}\right] \mathrm{DHM}$ used, this maximal stereospecific binding was equivalent to maximal saturable binding as determined with an excess $(10 \mu \mathrm{M})$ of unlabeled morphine. Thus, specific saturable binding of $\left[{ }^{3} \mathrm{H}\right] \mathrm{DHM}$ was considered representative of (stereospecific) opioid receptor binding. Analogous analyses were carried out for $\left[{ }^{3} \mathrm{H}\right] \mathrm{EKC}$ (used as a putative Kappa opiate) with the kappa enantiomers UM 1071R (active) and UM 1071S (inactive) [Medzihradsky et al, 1984]. Specific binding of $\left[{ }^{3} \mathrm{H}\right] \mathrm{ET}$ (nonselective) was determined only with an appropriate excess of the unlabeled opiate.

The attainment of binding equilibrium within 40 $\min$ at $25^{\circ} \mathrm{C}$ was tested with the lowest $(0.25 \mathrm{nM})$ and highest $(20 \mathrm{nM})$ concentrations at which direct binding of the radiolabeled opiates was investigated (data not shown). In a previous study, specific binding of $2 \mathrm{nM}$ $\left[{ }^{3} \mathrm{H}\right]$ naloxone in slices from mouse hippocampus reached equilibrium only after $120 \mathrm{~min}$ [Jacobson and Wilkinson, 1984]. Such slow equilibration is surprising considering pertinent observations with brain membranes, the experimental temperature of $30^{\circ} \mathrm{C}$, and the fact that the nonspecific binding of naltrexone was saturated already at $30 \mathrm{~min}$. As shown in a different study carried out with $20-\mu \mathrm{m}$ brain sections, the opioid receptor binding of $0.5-$ $6.0 \mathrm{nM}\left[{ }^{3} \mathrm{H}\right]$-naloxone was equilibrated in $30 \mathrm{~min}$ at room temperature [Geary and Wooten, 1983].

\section{Quantitiation of Opioid Receptor Binding}

The concentration dependence of $\left[{ }^{3} \mathrm{H}\right] \mathrm{ET}$, $\left[{ }^{3} \mathrm{H}\right] \mathrm{DHM}$, and $\left[{ }^{3} \mathrm{H}\right] \mathrm{EKC}$ binding showed that below $0.25 \mathrm{nM}$ of tritiated opiate the extent ligand binding was insufficient for accurate quantitiation, whereas at concentrations above $20 \mathrm{nM}$ the increasing contribution of nonspecific interactions masked the receptor binding. Within the concentration range of $0.25-20 \mathrm{nM}$, the Scatchard plots for specific binding of all three radiolabeled opiates were linear, with $K_{d}$ 's in the low nanomolar range (Fig. 2 and Table I). The binding data were also analyzed by the semilogarithmic plots shown as insets in Figure 2 [Klotz, 1982]. These curves are characterized by an inflection point at $50 \%$ of $\mathrm{B}_{\max }$, and are useful to confirm the number of binding sites obtained from respective Scatchard analyses, particularly in view of extensive nonspecific binding at high ligand concentrations.

In addition to Scatchard analysis, the binding data were evaluated by NONLIN, a weighted, nonlinear leastsquares regression analysis program, for fit to binding models of one saturable site, one saturable binding site plus one linear binding component, two saturable binding sites, and two saturable binding sites plus one linear binding component [Fischel and Medzihradsky, 1981, 1986]. The appropriateness of each binding model was evaluated by comparing the sum of weighted squared deviations using the $\mathrm{F}$ ratio test [Boxenbaum et al, 1974]. This evaluation showed that our data were best fit to a binding model of one population of saturable sites (Table I). In a previous study, $\left[{ }^{3} \mathrm{H}\right]$ naloxone bound to opioid receptors in slices from cortex and hyppocampus of the mouse brain with $K_{d}$ 's of 7.4 and $1.0 \mathrm{nM}$, and $B_{\max }$ values of 136 and $177 \mathrm{fmol} / \mathrm{mg}$ protein, respectively [Jacobson and Wilkinson, 1984].

\section{Heterogeneity of Opiate Binding in Brain Slices}

In the experiments on equilibrium binding of radiolabeled opiates, the large contribution of nonspecific associations precluded assessment of the low-affinity binding components seen in isolated brain membranes [e.g., Fischel and Medzihradsky, 1981]. Therefore, the approach of competitive displacement was applied [Molinoff et al, 1981]. In these experiments, the slices were incubated with $1 \mathrm{nM}$ of the nonselective opiate $\left[{ }^{3} \mathrm{H}\right] \mathrm{ET}$ 

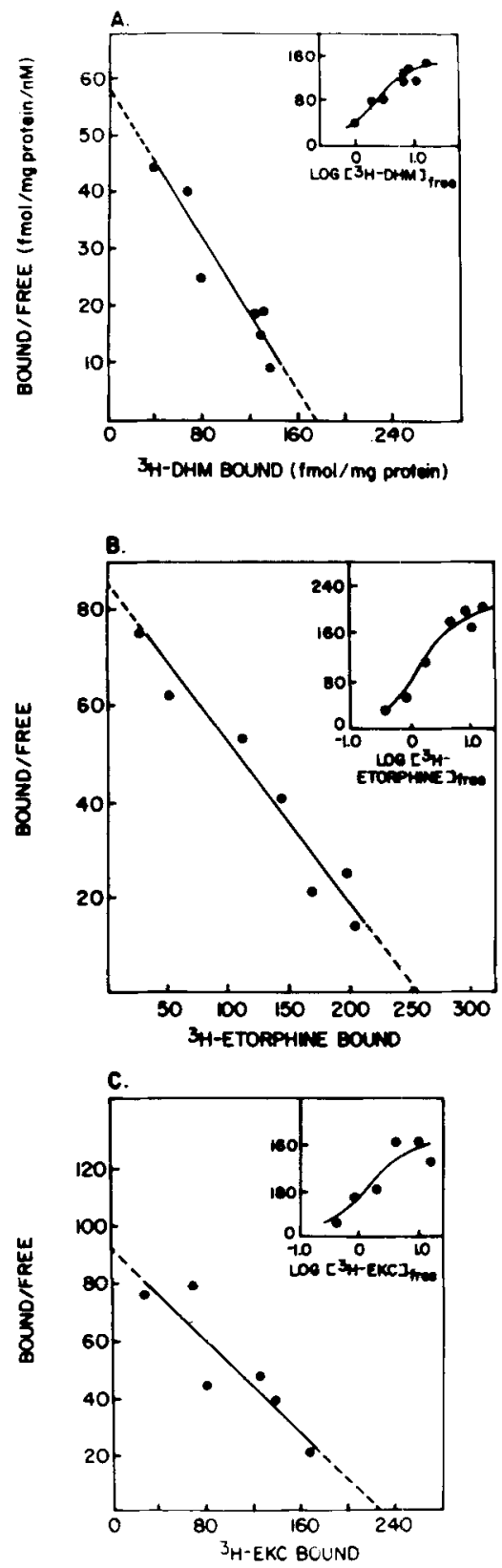

Fig. 2. Scatchard analysis of opiate binding in striatal slices, Following preincubation for $15 \mathrm{~min}$, the slices were incubated in artificial cerebrospinal fluid medium with $0.25-20 \mathrm{nM}$ of $\left[{ }^{3} \mathrm{H}\right] \mathrm{DHM}(\mathbf{A}),\left[{ }^{3} \mathrm{H}\right] \mathrm{ET}(\mathbf{B})$, or $\left[{ }^{3} \mathrm{H}\right] \mathrm{EKC}(\mathbf{C})$ to reach binding equilibrium, as described in the legend to Figure 1. The inset depicts an alternate presentation of the data characterized by an inflection point at $0.5 \mathrm{~B}_{\max }$ [Klotz, 1982]. Presented are the mean values obtained in three experiments carried out in duplicate. The statistical evaluation of the data is described in the legend to Table I.

and with increasing concentrations of either unlabeled etorphine, morphine, or ethylketocyclazocine (EKC), added concurrently with the radiolabeled ligand. $\left[{ }^{3} \mathrm{H}\right]$ Etorphine was displaced by unlabeled etorphine in a
TABLE I. Parameters of $\left[{ }^{3} \mathrm{H}\right]$ Opiate Binding in Brain Slices*

\begin{tabular}{llc}
\hline${ }^{3} \mathrm{H}$-Opiate & $\begin{array}{c}\mathrm{B}_{\max } \\
\text { (fmol/mg } \\
\text { protein) }\end{array}$ & $\begin{array}{c}\mathrm{K}_{\mathrm{d}} \\
(\mathrm{nM})\end{array}$ \\
\hline${ }^{3} \mathrm{H}$-dihydromorphine & $180 \pm 5$ & $3.70 \pm 0.11$ \\
${ }^{3} \mathrm{H}$-etorphine & $297 \pm 17$ & $2.83 \pm 0.21$ \\
${ }^{3}$ H-ethylketocyclazocine & $280 \pm 30$ & $3.61 \pm 0.31$ \\
\hline
\end{tabular}

*Specific $\Gamma^{3} \mathrm{H}$ lopiate binding $(0.25-20 \mathrm{nM})$ was determined as described in Materials and Methods. The listed values correspond to the Scatchard plots shown in Figure 2, and were obtained by applying NONLIN, a weighted nonlinear least-squares regression analysis program as described [Fischel and Medzihradsky, 1986]. For each $\left[{ }^{3} \mathrm{H}\right]$ opiate, the estimated parameters $\left(\mathrm{K}_{\mathrm{d}}\right.$ : equilibrium dissociation constant, $\mathrm{B}_{\max }$ : maximal ligand binding) are based on 20-24 data points obtained in three experiments. Shown are the means and standard deviations.

manner characteristic of equivalent, noninteracting sites (Fig. 3), yielding an EC50 of $4.6 \mathrm{nM}$ and a Hill coefficient of 0.94 (Table II). In contrast, the displacement curves obtained with morphine and EKC had shallow slopes spanning approximately $4 \log$ units of unlabeled ligand concentration (Fig. 3) and resulted in Hill coefficients of 0.62 and 0.47 , respectively. The high EC50 values for morphine and EKC (Table II) indicated that in contrast to the approach of direct binding (Fig. 2), lowaffinity sites were being revealed. It is of interest to note the similarity between the apparent $K_{d}$ values for etorphine obtained from direct binding and ligand displacement. On the other hand, the $\mathrm{K}_{\mathrm{d}}$ values generated by the displacement of bound $\left[{ }^{3} \mathrm{H}\right] \mathrm{ET}$ by morphine and EKC were considerably higher than those obtained by direct binding (Tables II and I).

In order to compare the selectivity of morphine and EKC in binding to opioid receptors, the displacement of $\left[{ }^{3} \mathrm{H}\right] \mathrm{DHM}$ by these two opiates was investigated. Morphine displaced $\left[{ }^{3} \mathrm{H}\right] \mathrm{DHM}$ over two log units of ligand concentration, characteristic of a population of equivalent, noninteracting sites (Fig. 4). In accordance, the Hill coefficient was close to unity (Table II). The value of $\mathbf{K}_{d}$ app, calculated from the corresponding EC50, was markedly similar to that determined by direct binding of $\left[{ }^{3} \mathrm{H}\right] \mathrm{DHM}$ (Tables I and II). L-EKC also displaced $\left[{ }^{3} \mathrm{H}\right] \mathrm{DHM}$ in a manner characteristic of a one-site binding model, yielded a Hill coefficient of 0.8 , and displayed an affinity similar to that of morphine (Fig. 4, Table II). In comparing the EC50 values in Table II, it should be noted that in contrast to DL-morphine and DLetorphine, the L-isomer of EKC was used.

\section{DISCUSSION}

This study explored the suitability of brain slices as a cellular preparation for the study of ligand interaction 

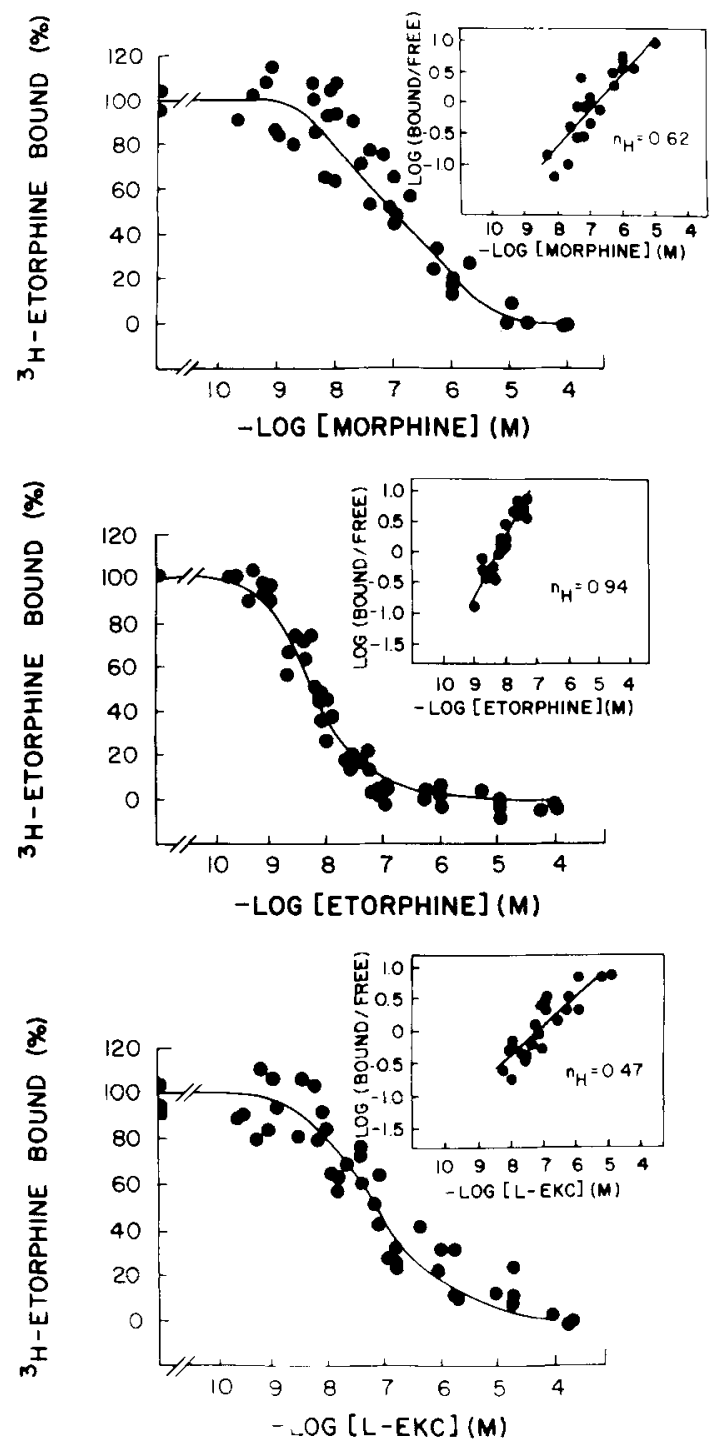

Fig. 3. Displacement of bound $\left[{ }^{3} \mathrm{H}\right] \mathrm{ET}$ by morphine, etorphine, and ethylketocyclazocine. Brain slices were incubated for $15 \mathrm{~min}$ as described in the legend to Figure 1. Subsequently, $\left.1 \mathrm{nM} \mathrm{[}{ }^{3} \mathrm{H}\right] \mathrm{ET}$ and unlabeled morphine (top panel), etorphine (middle panel), or ethylketocyclazocine (bottom panel) were added simultaneously at the concentrations indicated. After renewed incubation for $35 \mathrm{~min}$, the assay was terminated by rapid filtration as described in Materials and Methods. The insets depict the data as a Hill plot. Each experiment was carried out in duplicate, and the results were averaged. Shown are all the averages obtained in three experiments. The curves were drawn with the aid of the weighted, nonlinear least-squares regression analysis program BMDX85 , obtained from the Health Science computing Facility, University of California, Los Angeles.

with opioid receptor. In view of the high density of opioid receptors in striatum, this brain region was selected as the tissue source [Pert and Snyder, 1973]. The slices accumulated potassium against its concentration gradient, a stringent criterion of cellular viability [Fischel and Medzihradsky, 1985]. Functional integrity of the slices was previously demonstrated [Barchfeld et al, 1982] by the opioid-receptor-mediated inhibition of PGE-induced adenylate cyclase under experimental conditions similar to those used for ligand binding in the present work. In contrast to slices, PGE stimulation of the enzyme and its sensitivity to opiates was abolished in isolated brain membranes [Katz and Catravas, 1977].

In a previous study on opioid receptor binding of $\left[{ }^{3} \mathrm{H}\right]$ naloxone in slices from mouse brain [Jacobson and Wilkinson, 1984] ligand concentration was limited to 12 $\mathrm{nM}$, thus excluding the assessment of low affinity sites, i.e., hampering the assessment of opioid receptor heterogeneity. In the present work, the approach of competitive displacement, applied in addition to direct equilibrium binding of the radiolabeled opiates, allowed the study of ligand binding to receptor sites with widely diverging affinities.

The results of direct receptor binding suggested that radiolabeled etorphine, dihydromorphine, and $\mathrm{EKC}$ bound to a population of noninteracting sites with similar high affinities. The corresponding Scatchard plots were linear with no indication of cooperativity. Computer fitting to binding models with more than one site did not improve the resolution of the data. Furthermore, $1 \mathrm{nM}$ $\left[{ }^{3} \mathrm{H}\right] \mathrm{ET}$ was displaced by increasing concentrations of unlabeled etorphine in a homogenous manner, as indicated by an appropriate displacement profile and Hill coefficient. On the other hand, the displacement profiles of $\left[{ }^{3} \mathrm{H}\right] \mathrm{ET}$ by morphine and EKC were characterized by shallow slopes, spanning approximately 4 log-units of unlabeled drug concentration and by Hill coefficients of 0.62 and 0.47 , respectively. The relatively high EC50 values for the two opiates (Table II) indicated that in addition to the high-affinity sites $\left(\mathrm{K}_{\mathrm{d}}\right.$ 's approximately 2$5 \mathrm{nM}$ ) measured by direct binding (Fig. 2), sites with lower affinity were revealed in the displacement experiments (Fig. 3). Apparently, morphine and EKC share with etorphine a population of high-affinity sites, but are recognized with much lower affinity by an additional set of sites labeled by $\left[{ }^{3} \mathrm{H}\right] \mathrm{ET}$.

It is of interest that the EC50 values for the displacement of $\left[{ }^{3} \mathrm{H}\right]$ etorphine by morphine and EKC (Table II) were similar to the respective IC50's of these opiates in inhibiting PGE-induced adenylate cyclase in brain slices [Barchfeld et al, 1982]. Since the binding and inhibition of adenylate cyclase were measured under comparable experimental conditions, it seems reasonable to postulate that the low-affinity sites may be involved in the coupling of opioid receptor to adenylate cyclase. In that respect, recent experiments have shown that following alkylation of the high-affinity opioid receptor sites in brain membranes, the binding of ligands to the residual low-affinity sites still induced the stimulation of low- $\mathrm{K}_{\mathrm{m}}$ GTPase [Clark and Medzihradsky, 1986].

In isolated brain membranes from the rat and guinea pig, etorphine was described as a nonselective ligand that 
TABLE II. Displacement of Bound $\left[{ }^{3} \mathrm{H}\right] \mathrm{ET}$ and $\left[{ }^{3} \mathrm{H}\right] \mathrm{DHM}$ by Opiates in Brain Slices*

\begin{tabular}{|c|c|c|c|}
\hline Displacing ligand & $\begin{array}{l}\text { EC50 } \\
(\mathrm{nM})\end{array}$ & $\begin{array}{c}\mathrm{K}_{\mathrm{d}} \text { app } \\
(\mathrm{nM})\end{array}$ & $\begin{array}{c}\text { Hill } \\
\text { coefficient }\end{array}$ \\
\hline \multicolumn{4}{|l|}{ A. $\left[{ }^{3} \mathrm{H}\right]$ ET binding } \\
\hline Etorphine & 6.3 & 4.6 & 0.94 \\
\hline Morphine & 126.0 & 92.5 & 0.62 \\
\hline L-Ethylketocyclazocine & 63.1 & 49.3 & 0.47 \\
\hline \multicolumn{4}{|l|}{ B. $\left[{ }^{3} \mathrm{H}\right]$ DHM binding } \\
\hline Morphine & 5.0 & 3.9 & 0.88 \\
\hline L-Ethylketocyclazocine & 3.5 & 2.7 & 0.80 \\
\hline
\end{tabular}

*The listed values correspond to the plots shown in Figures 3 and 4. The apparent ligand dissociation constant ( $\mathrm{K}_{\mathrm{d}}$ app) was calculated according to the following formula [Cheng and Prusoff, 1973]:

$$
\mathrm{K}_{\mathrm{d}} \text { app }=\frac{\mathrm{EC50}}{1+[\mathbf{L}] / \mathbf{k}_{\mathrm{d}}}
$$

Statistical information is listed in the legends to Figures 3 and 4.

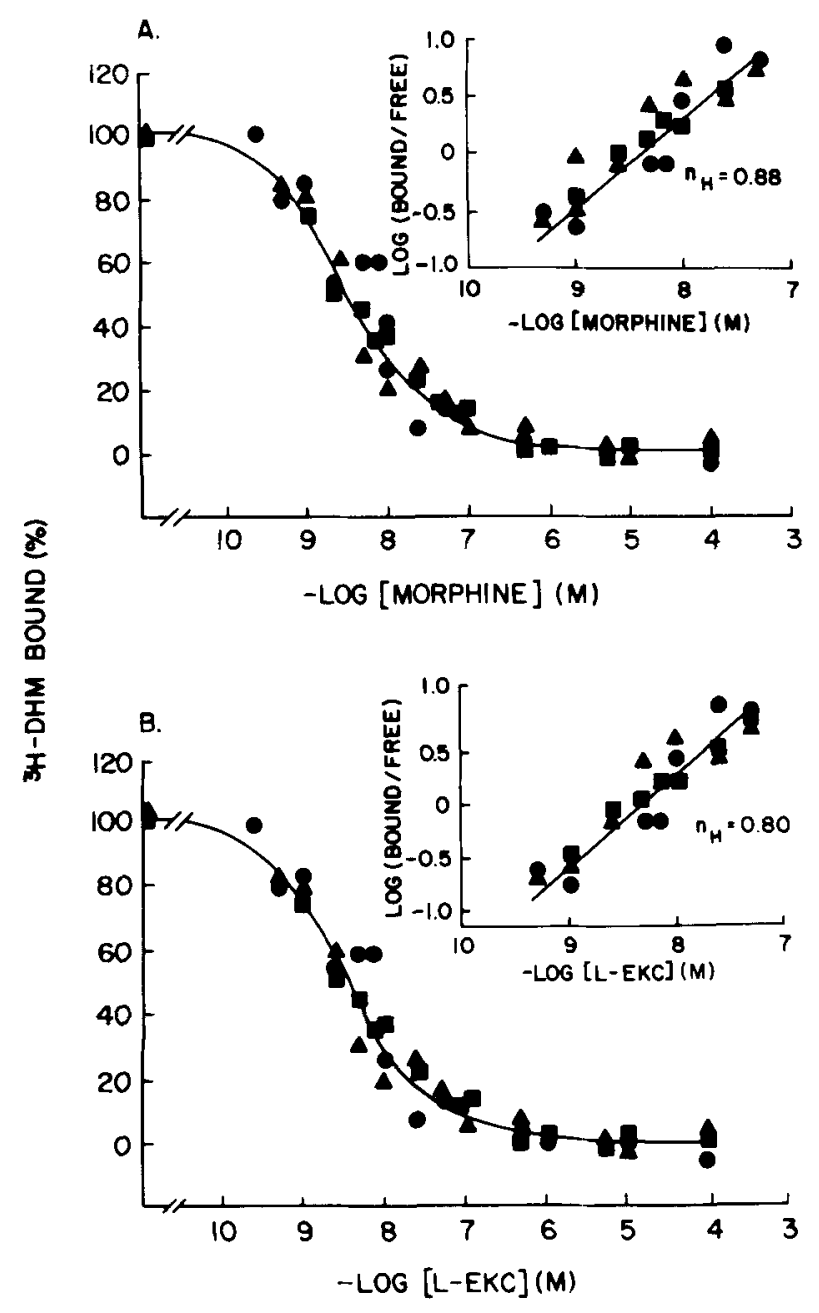

bound to mu, kappa, and delta receptors [Fischel and Medzihradsky, 1986; Clark and Medzihradsky, 1987; Kosterlitz and Patterson, 1980]. On the other hand, as determined by the in vivo technique, $\left[{ }^{3} \mathrm{H}\right] \mathrm{ET}$ bound to sites with mu-receptor properties [Rosenbaum et al, 1984], but was displaced by morphine with a potency that was more than 140 -fold lower than that for EKC [Rosenbaum et al, 1985].

In a comparative study, involving the measurement of analgesia and opiate dependence in the mouse [Von Voigtlander and Lewis, 1982], EKC displayed lower kappa selectivity than the newly introduced ligand U50,488 [Von Voigtlander et al, 1983]. In rat brain membranes, the characteristics of EKC binding were similar to those of naltrexone [Fischel and Medzihradsky, 1981] and etorphine [Fischel and Medzihradsky, 1986], opiates of limited binding selectivity. However, in behavioral studies, EKC displayed typical kappa agonist activity [Woods et al, 1979], and has subsequently frequently been used as a kappa ligand [e.g., Garzon et al, 1984]. Nonetheless, the in vivo binding of $\left[{ }^{3} \mathrm{H}\right] \mathrm{EKC}$ was characterized by low affinity and large scatter of the data. The binding was saturable and reflected interaction with kappa, mu, and delta sites [Rosenbaum et al, 1985]. These discrepancies between the results obtained with isolated brain membranes, brain slices, and rats in vivo underline the need for additional studies of opioid recep-

Fig. 4. Displacement of bound $\left[{ }^{3} \mathrm{H}\right] \mathrm{DHM}$ by morphine and ethylketocyclazocine. The slices were preincubated and then incubated as described in the legend to Figure 3 with $1 \mathrm{nM}$ $\left[{ }^{3} \mathrm{H}\right] \mathrm{DHM}$ and morphine (A) or ethylketocyclazocine (B) at the concentrations indicated. The insets depict Hill plots of the data. Shown are the averages of duplicate determinations obtained in three experiments $(\boldsymbol{O}, \mathbf{\Delta}, \mathbf{\square})$. 
tor mechanisms in intact cellular systems in which the properties of multiple opioid receptors reflect cell-cell interactions and the effects of diverse cellular modulators, present at appropriate concentrations.

\section{ACKNOWLEDGMENTS}

This work was supported in part by USPHS grant DA 00254.

\section{REFERENCES}

Barchfeld CD, Maassen ZF, Medzihradsky F (1982): Receptor-related interactions of opiates with PGE-induced adenylate cyclase in brain. Life Sci 31:1661-1665.

Blume AJ (1978): Interaction of ligands with the opiate receptors of brain membranes: Regulation by ions and nucleotides. Proc Natl Acad Sci USA 75:1713-1717.

Blume AJ, Lichtstein D, Boone G (1979): Coupling of opioid receptors to adenylate cyclase: Requirement for $\mathrm{Na}^{+}$and GTP. Proc Natl Acad Sci USA 76:5626-5630.

Boxenbaum HG, Riegelman S, Elashoff RM (1974): Statistical estimations in pharmacokinetics. J Pharmacokinet Biopharmacol 2:123-148.

Chang KJ, Blanchard SG, Cuatrecasas P (1983): Unmasking of magnesium-dependent high-affinity binding sites for $\left[D-a^{2}{ }^{2}, D-\right.$ leu ${ }^{5}$ ]enkephalin after pretreatment of brain membranes with guanine nucleotides Proc Natl Acad Sci USA 80:940-944.

Cheng Y-C, Prusoff WH (1973) Relationship between the inhibition constant $(\mathrm{Ki})$ and the concentration of inhibitor which causes 50 percent inhibition (IC50) of an enzymatic reaction. Biochem Pharmacol 22:3099-3108.

Clark MJ, Medzihradsky F (1986): Spare ligand binding sites in the coupling of opioid receptor to brain GTPase. Res Monogr Natl Inst Drug Abuse 75:145-148.

Clark MJ, Levenson SD, Medzihradsky F (1986): Evidence for coupling of the kappa opioid receptor to brain GTPase. Life Sci 39:1721-1727.

Clark MJ, Medzihradsky F (1987): Coupling of multiple opioid receptors to GTPase following selective receptor alkylation in brain membranes. Neuropharmacology (in press).

Davis ME, Akera T, Brody TM, Watson L (1977): Opiate receptor: Cooperativity of binding observed in brain slices. Proc Natl Acad Sci USA 74:5764-5766.

Fischel SV, Medzihradsky F (1981): Scatchard analysis of opiate receptor binding. Mol Pharmacol 20:269-279.

Fischel SV, Medzihradsky F (1985): Assessment of membrane permeability in primary cultures of neurons and glia in response to osmotic perturbation. J Neurosci Res 13:369-380.

Fischel SV, Medzihradsky F (1986): Interaction between $\left[{ }^{3} \mathrm{H}\right]$ ethylketocyclazocine and $\left[{ }^{3} \mathrm{H}\right]$ etorphine and opioid receptors in membranes from rat brain: A kinetic analysis. Neuropharmacology 25:351-359.

Frost JJ, Dannals RF, Duelfer T, Burns HD, Ravert HT, Langstrom B, Balasubramanian V, Wagner HN, Jr (1984): In vivo studies of opiate receptors. Ann Neurol 15:S85-S92.

Garzon J, Sanchez-Blazquez P, Lee NM (1984): $\left[{ }^{3} \mathrm{H}\right]$ ethylketocylazocine binding to mouse brain membranes: Evidence for a kappa opioid receptor type. J Pharmacol Exp Ther 231:33-37.

Geary NA, Wooten GF (1983): Quantitative film autoradiography of opiate agonist and antagonist binding in rat brain. $J$ Pharmacol Exp Ther 225:234-240.

Gillan MGC, Kosterlitz HW (1982): Spectrum of the mu-, delta-, and kappa-binding sites in homogenates of rat brain. $\mathrm{Br} \mathrm{J}$ Pharmacol 77:461-469.
Goodman RR, Snyder SH (1982): Kappa opiate receptors localized by autoradiography to deep layers of cerebral cortcx: Relation to sedative effects. Proc Natl Acad Sci USA 79:5703-5707.

Goodman FR, Weiss GB, Alderdice MT (1973): On the measurement of extracellular space in slices prepared from different rat brain areas. Neuropharmacology 12:867-873.

Herkenham M, Pert CB (1981): Opiate receptor gradients in monkey cerebral cortex: Correspondence with sensory processing hierarchies. Science 211:1166-1169.

Jacobson W, Wilkinson $\mathrm{M}$ (1984): Opiate $\left(\left[{ }^{3} \mathrm{H}\right]\right.$-naloxone) binding to hypothalamic and cerebral cortical slices of mouse brain. Brain Res Bull 13:481-485.

James IF, Goldstein A (1984): Site-directed alkylation of multiple opioid receptors. I. Binding selectivity. Mol Pharmcol 25:337342.

Katz JB, Catravas GN (1977): Absence of morphine antagonism of prostaglandin $\mathrm{E}_{1}$-stimulated $\left[{ }^{3} \mathrm{H}\right] 3^{\prime}, 5^{\prime}$-cyclic adenosine monophosphate accumulation in a rat brain mince system. Brain Res 120:263-268.

Klotz IM (1982): Numbers of receptor sites from Scatchard graphs: Facts and fantasies. Science 217:1247-1248.

Kosterlitz HW, Paterson SJ (1980): Characterization of opioid receptors in nervous tissue. Proc R Soc Lond [Biol]210:113-122.

Lowry OH, Rosebrough NJ, Farr AL, Randall RJ (1951): Protein measurement with the Folin phenol reagent. J Biol Chem 1983:265-275.

McIlwain H, Rodnight R (1962): "Practical Neurochemistry." London: Churchill JA, p 206.

Medzihradsky F (1976): Stereospecific binding of etorphine in isolated neural cells and retina, determined by a sensitive microassay. Brain Res 108:212-219.

Medzihradsky F, Dahlstrom PJ, Woods JH, Fischel SV, Mitsos SE (1984): Resolution in the receptor binding of putative $\mathrm{mu}$ and kappa opiates. Life Sci 34:2013-2022.

Molinoff PB, Wolfe BB, Weiland Ga (1981): Quantitative analysis of drug-receptor interactions: Determination of the properties of receptor subtypes. Life Sci 39:427-443.

Pappius HM, Klatzo I, Elliott KAC (1962): Further studies on swelling of brain slices. Can J Biochem Physiol 40:885-898

Pert CB, Snyder SH (1973): Opiate receptor: Demonstration in nervous tissue. Science 179:1011-1014.

Peterson GL (1979): Review of the Folin phenol protein quantitation method of Lowry, Rosebrough, Farr and Randall. Anal Biochem 100:201-220.

Rogers NF, El-Fakahany EE (1985): Intact cells: A novel model system for studying opioid receptor binding. Life Sci 37:307314.

Rosenbaum JS, Holford NHG, Richards ML, Aman RA, Sadee W (1984): Discrimination of three types of opioid binding sites in rat brain in vivo. Mol Pharmacol 25:242-248.

Rosenbaum JS, Holford NHG, Sadee W (1985): In vivo receptor binding of opioid drugs at the mu site. J Pharmacol Exp Ther 233:735-740.

Simantov R, Levy R, Baram D (1982): Down regulation of enkephalin (delta) receptors; demonstration in membrane-bound and solubilized receptors. Biocnem Biophys Acta 721:478-484.

Von Voigtlander PF, Lewis RA (1982): U-50, 488, a selective kappa opioid agonist: Comparison to other reputed kappa agonists. Prog Neuropsychopharmacol Biol Psychiatry 6:467-470.

Von Voigtlander PF, Lahti RA, Ludens JH (1983) U-50,488: A selective and structurally novel non-mu (kappa) opioid agonist. $\checkmark$ Pharmacol Exp Ther 224:7-12.

Woods JH, Smith CB, Medzihradsky F, Swain JH (1979): Preclinical testing of new analgesic drugs. In Beers RF, Jr, Basset EG (eds): "Mechanisms of Pain and Analgesia. New York: Raven Press, pp 429-445. 